\title{
Use of SPAD index in elephant grass pre-breeding
}

\section{Uso do índice SPAD em pré-melhoramento de capim elefante}

\author{
Pérsio Sandir D’Oliveira ${ }^{1 *}$; Letícia Sayuri Suzuki²; Jailton da Costa Carneiro²; \\ Juarez Campolina Machado²; Jader Forquim Prates 3 ; João Romero do Amaral \\ Santos de Carvalho Rocha ${ }^{4}$
}

\section{Highlights:}

The use of morphoagronomic descriptors in pre-breeding is costly and time consuming. We proposed screening elephant grass genotypes using SPAD index.

We found SPAD index was effective in separate Cameroon from Napier genotypes.

\begin{abstract}
The SPAD-502 (Soil Plant Analysis Development) chlorophyll meter is a simple diagnostic tool that instantly measures the chlorophyll content of plant leaves without damaging the leaf blade. This study aimed to evaluate the efficacy of the SPAD index as a tool for discriminating elephant grass acessions from different morphological groups. One hundred genotypes of the elephant grass Pennisetum purpureum from the Active Germplasm Bank at Embrapa Dairy Cattle, Minas Gerais, Brazil were evaluated. Following uniform cutting, six SPAD readings were taken from each accession every 60 days. Measurements were taken for two years. The experimental design was a $10 \times 10$ simple lattice with two replications. Joint deviance analysis for six SPAD measurements revealed great genetic variability between genotypes. SPAD values of Cameroon and Napier accessions were, on average, significantly different. The SPAD index was effective in detecting genetic variability between elephant grass acessions. However, it should not be used alone as a morphological descriptor, but in combination with other descriptors.
\end{abstract}

Key words: Chlorophyll meter. Crop breeding. Pennisetum purpureum.

\section{Resumo}

O clorofilômetro SPAD-502 (Soil Plant Analysis Development) é usado na medição indireta do conteúdo de clorofila, e é caracterizado pela rapidez e simplicidade, especialmente por ser uma medição não destrutiva do limbo foliar. O objetivo desse trabalho foi avaliar o índice SPAD como ferramenta para identificar acessos de diferentes grupos morfológicos de capim-elefante. Foram avaliados 100 genótipos do Banco Ativo de Germoplasma de Capim-elefante da Embrapa Gado de Leite, Minas Gerais, Brasil. Após corte de uniformização, foram realizadas seis leituras por acesso, a cada 60 dias. As medidas foram realizadas durante dois anos. O delineamento experimental foi o látice simples $(10 \mathrm{x} 10) \mathrm{com}$

\footnotetext{
1 Pesquisador, Dr., Empresa Brasileira de Pesquisa Agropecuária, Embrapa Gado de Leite, Juiz de Fora, MG, Brasil. E-mail: persio.oliveira@embrapa.br

2 Pesquisadores, Drs., Embrapa Gado de Leite, Juiz de Fora, MG, Brasil. E-mail: leticia.suzuki@embrapa.br; jailton.carneiro@ embrapa.br; juarez.machado@embrapa.br

3 Zootecnista, Bacharel, Instituto Federal de Educação, Ciência e Tecnologia do Sudeste, IF Sudeste, Rio Pomba, MG, Brasil. E-mail: jader.forquimprates@yahoo.com.br

4 Pesquisador, Dr., Universidade Federal de Viçosa, UFV, Viçosa, MG, Brasil. E-mail: joaoascrocha@gmail.com

* Author for correspondence
} 
duas repetições. Foi observado efeito de acessos pela análise conjunta de deviance das seis medidas do índice SPAD mostrando alta variabilidade genética entre os materiais. Os grupos 'Cameroon'e 'Napier' foram diferentes entre si para o índice SPAD, que se mostrou eficaz na detecção de variabilidade genética entre cultivares; contudo, deve ser usado juntamente com outros descritores e não exclusivamente como descritor morfológico.

Palavras-chave: Clorofilômetro. Melhoramento vegetal. Pennisetum purpureum.

Elephant grass [Pennisetum purpureum Schum.; synonym Cenchrus purpureus (Schumach.) Morrone], native to Africa and introduced in Brazil as forage, is a promising source of renewable energy (J. R. A. S. C. Rocha et al., 2017). Elephant grass is a tall, erect, perennial plant with cespitose habit, cylindrical and full stems, broad and long leaves, and high biomass yield. For breeding purposes, the phenotypic description of elephant grass accessions requires the analysis of a set of morphoagronomic descriptors, including morphological, reproductive, agronomic, and biochemical traits (Pereira, 1999). However, using these descriptors is costly and time consuming, and tools are required to facilitate the work.

The SPAD-502 (Soil Plant Analysis Development) chlorophyll meter is a simple diagnostic tool that instantly measures the relative chlorophyll content of leaves without damaging the leaf blade that has been increasingly used to improve crop and pasture quality. The 'greenness' of the leaves is detected by measuring the amount of wavelength light absorbed by the leaf in the red and infrared regions. The absorbance in the red region indicates the amount of chlorophyll present, whereas the absorbance in the near-infrared region compensates for the thickness and water content of the leaf (R. N. C. Rocha et al., 2005; Silva, Jifon, Silva, \& Sharma, 2007; Amarante et al., 2010; Araújo et al., 2013; Souza, Modesto, Pompeu, \& Natale, 2014).

The efficiency of a dimensionless SPAD index as an indirect measure of chlorophyll content has been demonstrated in studies with various crops, including brachiaria grass (Maranhão, Silva,
Bonono, \& Pires, 2009), dwarf elephant grass (Araújo et al., 2013), sugarcane (Silva et al., 2007), and maize (R. N. C. Rocha et al., 2005; Amarante et al., 2010; Hurtado, Resende, Silva, Corazza, \& Shiratsuchi, 2011). In addition, the SPAD index has been shown to correlate with dry matter yield (Souza et al., 2014). In maize, the SPAD index correlated with grain yield when the plant was at the four and eight fully expanded leaves stages ( $R$. N. C. Rocha et al., 2005). Moreover, chlorophyll meter readings (SPAD) can be used to select stressadaptive maize genotypes (Gekas et al., 2013). In sugarcane, the SPAD index correlated with drought tolerance or susceptibility (Silva, Santos, Vitorino, \& Rhein, 2014). This study aimed to evaluate the efficacy of the SPAD index as a morphological descriptor of elephant grass genotypes from different morphological groups in pre-breeding programs.

The trial was conducted in the Active Germplasm Bank at Embrapa Dairy Cattle (BAGCE) in Coronel Pacheco, Zona da Mata region, southeastern

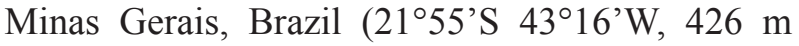
asl). The climate is Cwa according to the Köppen classification with hot and rainy summers and dry winters.

The experiment was conducted on 4-m single row plots spaced $1.5 \mathrm{~m}$ apart arranged in a $10 \times 10$ simple lattice design with two replications, totaling 100 genotypes: Cameroon (18), Napier (44), Mercker (5), and Dwarf (1), in addition to 32 genotypes that could not be assigned to specific varieties because of their unique morphological traits. Nitrogen-phosphorus-potash solid fertilizer (05-20-20) was applied annually at a rate of $250 \mathrm{~kg}$ $\mathrm{ha}^{-1}$. SPAD readings were taken at the middle of 
the leaf lamina away from the primary vein using a SPAD-502Plus chlorophyll meter (Konica Minolta Sensing Inc, Osaka, Japan) every 60 days following uniform cutting. Measurements were taken for two years.

Statistical analyses were performed using the REML/BLUP (restricted maximum likelihood/best linear unbiased prediction) methodology according to Patterson and Thompson (1971) and Henderson (1975). In the random effects models, the level of significance for the likelihood-ratio test (LRT) was assessed using the chi-square test with one degree of freedom. Mean SPAD values were compared between the groups by the F-test using the SelegenREML/BLUP software (Resende, 2007).
Joint deviance analysis of six SPAD measurements revealed a significant effect of genotype on SPAD values (Table 1), revealing a great genetic variability among the 100 BAGCE elephant grass genotypes investigated. In addition, there was a significant effect $(p<0.05)$ of the genotype $\times$ measurement time interaction on SPAD values (Table 1), indicating that the time of year of SPAD readings affects the accession ranking, based on this parameter. Also, more than one SPAD measurement is needed to predict genetic value with high accuracy. The accuracy of the SPAD index depends on several factors, including leaf maturity and phenological stage, and may be affected by seasonality (Amarante et al., 2010; Silva et al., 2014).

Table 1

Joint deviance analysis for six SPAD measurements in 100 elephant grass (Pennisetum purpureum) genotypes

\begin{tabular}{ccccccc}
\hline \multirow{2}{*}{ Variable } & \multicolumn{6}{c}{ Effect } \\
\cline { 2 - 6 } & Accession + & Block + & $\begin{array}{c}\text { Accession } \times \\
\text { measurements }+\end{array}$ & $\begin{array}{c}\text { Permanent envi- } \\
\text { ronment }+\end{array}$ & $\begin{array}{c}\text { Complete } \\
\text { model }\end{array}$ \\
\hline $\begin{array}{c}\text { SPAD in- } \\
\text { dex }\end{array}$ & Deviance & 4616.68 & 4612.51 & 4612.98 & 4654.29 & 4606.78 \\
\cline { 2 - 7 } & LRT $\left(X^{2}\right)$ & $9.9^{* *}$ & $5.73^{*}$ & $6.2^{*}$ & $47.51^{* *}$ & - \\
\hline
\end{tabular}

Chi-square: 3.84 and 6.63 for $5 \%$ and $1 \%$ significance levels, respectively.

**: significant at $1 \%$ by the chi-square test; *: significant at $5 \%$ by the chi-square test. + : Deviance of the model adjusted without these effects. LRT $\left(\mathrm{X}^{2}\right)$ : likelihood ratio test.

The F-test for the effect of genotype showed a significant difference $(p<0.05)$ in SPAD values between the Cameroon and Napier groups (Table 2). Thus, SPAD values of Cameroon and Napier groups are, on average, significantly different. However, no significant differences in SPAD values were detected between the other groups. 
Table 2

Deviance analysis for elephant grass (Pennisetum purpureum) genotypes Cameroon and Napier and F-test for the effect of Cameroon vs. Napier genotypes on the SPAD index

\begin{tabular}{lcccc}
\hline Effect & Deviance & LRT $\left(X^{2}\right)$ & & \\
\hline Cameroon & $72.24+$ & $69.63^{* *}$ & & \\
Complete model & 2.61 & - & & \\
\hline Napier & $438.15+$ & $301.73^{* *}$ & & \\
Complete model & 136.42 & - & MS $=4.05$ & P-value $=0.02$ \\
\hline Cameroon vs. Napier & DF $=1$ & $\mathrm{SQ}=4.05$ & \\
\hline Overall mean & 29.96 & - & \\
Cameroon mean & 29.8 & - & \\
Napier mean & 30.03 & - & & \\
\hline CV $(\%)$ & 1.81 & & & \\
\hline
\end{tabular}

Chi-square: 3.84 and 6.63 for $5 \%$ and $1 \%$ significance levels, respectively.

**: significant at $1 \%$ by the chi-square test; *: significant at $5 \%$ by the chi-square test.

DF: degree of freedom. CV: coefficient of variation

+: Deviance of the model adjusted without these effects. LRT $\left(\mathrm{X}^{2}\right)$ : likelihood ratio test.

The six SPAD measurements taken from the BAGCE genotypes had a coefficient of repeatability (CoR) of 0.32. According to Resende (2007), CoR values greater than 0.6 indicate high repeatability, CoR values between 0.3 and 0.6 indicate intermediate repeatability, and CoR values smaller than 0.3 indicate low repeatability. The CoR value computed in this study (0.32) indicates that six SPAD measurements were sufficient to predict the genotypic value of elephant grass groups with $86 \%$ accuracy, which refers to the correlation between predicted and true genetic values of individuals (Pimentel et al., 2014).

In Cameroon elephant grass, eight readings were sufficient to estimate the chlorophyll content of leaves by the SPAD index with an acceptable error of $10 \%$, whereas 16 and 80 SPAD measurements were required to determine the macronutrient and micronutrient content of plants, respectively (Souza et al., 2014). In sugarcane, five measurements from different plants within the same plot were sufficient to demonstrate a correlation between the SPAD index and drought tolerance (Silva et al., 2007).
In maize, five readings from different plants were sufficient to satisfactorily demonstrate a correlation between the SPAD index and plant nutritional status (Hurtado et al., 2011).

The SPAD index accurately discriminated between Cameroon and Napier groups. There was great variability between genotypes within each elephant grass group. In addition, there was a significant interaction between SPAD values and environmental factors. Finally, the SPAD index was effective in detecting genetic variability between elephant grass accessions; however, it should not be used alone as a morphological descriptor, but in combination with other descriptors (dry matter, crude protein, plant height).

\section{References}

Amarante, C. V. T., Steffens, C. A., Sangoi, L., Zanardi, O. Z., Miqueloto, A., \& Scheitzer, C. (2010). Quantificação de clorofilas em folhas de milho através de métodos ópticos não destrutivos. Revista Brasileira de Milho e Sorgo, 9(1), 39-50. doi: 10.18512/1980-6477/rbms.v9n1p39-50 
Araújo, S. A. C., Vasquez, H. M., Torres Netto, A., Capostrini, E., Deminicis, B. B., \& Lima, E. S. (2013). Indirect method for quantifying the content of photosynthetic pigments in genotypes of dwarf elephant grass. Acta Scientiarum Animal Science, 35(1), 43-47. doi: 10.4025/actascianimsci. v35i1.15178

Gekas, F., Pankou, C., Mylonas, I., Ninou, E., Sinapidou, E., Lithourgidas, A.,... Dordas, C. (2013). The use of chlorophyll meter readings for the selection of maize inbred lines under drought stress. International Journal of Biological, Biomolecular, Agricultural, Food and Biotechnological Engineering, 7(8), 4246. doi: 10.5281/zenodo. 1087546

Henderson, C. R. (1975). Best linear unbiased estimation and prediction under a selection model. Biometrics, 31(2), 423-447. doi: 10.2307/2529430

Hurtado, S. M. C., Resende, A. V., Silva, C. A., Corazza, E. J., \& Shiratsuchi, L. S. (2011). Clorofilômetro no ajuste da adubação nitrogenada em cobertura para o milho de alta produtividade. Ciência Rural, 41(6), 1011-1017. doi: 10.1590/S010384782011005000074

Maranhão, C. M. A., Silva, C. C. F., Bonomo, P., \& Pires, A. J. V. (2009). Produção e composição químicobromatológica de duas cultivares de braquiária adubadas com nitrogênio e sua relação com o índice SPAD. Acta Scientiarum. Animal Science, 31(2), 117-122. doi: 104025/actascianimsci.v31i2.4305

Patterson, H. D., \& Thompson, R. (1971). Recovery of inter-block information when block sizes are unequal. Biometrika, 58(3), 545-554. doi: 10.2307/2334389

Pereira, A. V. (1999). Germoplasma e diversidade genética do capim-elefante (Pennisetum purpureum Schum.). In L. P. Passos, L. A. Carvalho, C. E. Martins, M. Bressan, \& A. V. (Eds.), Pereira, Biologia e manejo do capim-elefante. Juiz de Fora: EMBRAPA Gado de Leite.
Pimentel, A. J. B., Guimarães, J. F. R., Souza, M. A., Resende, M. D. V., Moura, L. M., \& Rocha, J. R. A. S. C. (2014). Estimation of genetic parameters and prediction of additive genetic value for wheat by mixed models. Pesquisa Agropecuária Brasileira, 49(11), 882-890. doi: 10.1590/S0100204X20140011000007

Resende, M. D. V. (2007). Selegen-Rem/BLUP: sistema estatístico e seleção genética computadorizada via modelos lineares mistos. Colombo: EMBRAPA Florestas.

Rocha, J. R. A. S. C., Machado, J. C., Carneiro, P. C. S., Carneiro, J. C., Resende, M. D. V., Lédo, F. J. S., \& Carneiro, J. E. S. (2017). Bioenergetic potential and genetic diversity of elephantgrass via morphoagronomic and biomass quality traits. Industrial Crops and Products, 95(1), 485-492. doi: 10.1016/j. indcrop.2016.10.060

Rocha, R. N. C., Galvão, J. C. C., Teixeira, P. C., Miranda. G. V., Agnes, E. L., Pereira, P. R. G., \& Leite, V. T. (2005). Relação do índice SPAD, determinado pelo clorofilômetro, com teor de nitrogênio na folha e rendimento de grãos em três genótipos de milho. Revista Brasileira de Milho e Sorgo, 4(2), 161-171. doi: 10.18512/1980-6477/rbms.v4n2p161-171

Silva, M. A., Jifon, J. L., Silva, J. A. G., \& Sharma, V. (2007). Use of physiological parameters as fast tools to screen for drought tolerance in sugarcane. Brazilian Journal of Plant Physiology, 19(3), 193201. doi: 10.1590/S1677-0420200700300003

Silva, M. A., Santos, C. M., Vitorino, H. S., \& Rhein, A. F. (2014). Pigmentos fotossintéticos e índice SPAD como descritores de intensidade do estresse por deficiência hídrica em cana-de-açúcar. Bioscience Journal, 30(1), 173-181. doi: not available

Souza, H. A., Modesto, V. C., Pompeu, R. C. F. F., \& Natale, W. (2014). Tamanho da amostra foliar para avaliação do estado nutricional e índice SPAD de capim-elefante irrigado para corte. Revista Brasileira de Saúde e Produção Animal, 15(3), 584-591. doi: 10.1590/S1519-99402014000300005 
